\title{
РОЗВИТОК СИСТЕМИ ОСВІТИ ОБДАРОВАНИХ ДІТЕЙ У КИТАї
}

\section{Бао Шуцзюань}

здобувач третього (освітньо-наукового) рівня вищої освіти кафедри освітології та інноваційної педагогіки, Харківський національний педагогічний університет імені Г. С. Сковороди, м. Харків, Україна

\section{Хуан Тівень}

здобувач третього (освітньо-наукового) рівня вищої освіти кафедри освітології та інноваційної педагогіки, Харківський національний педагогічний університет імені Г. С. Сковороди, м. Харків, Україна

У статті викладено основні підходи до організації освіти обдарованих дітей у Китаї. Встановлено, щзо стратегії та зміст навчання обдарованих дітей в Украӥні та Китай мають як подібність, і специфічні особливості. Наведено аналіз системи організачї освіти обдарованих дітей у Китаї, щуо регулюється державою.

Ключові слова: освітній прочес, заклади освіти, обдаровані діти, розвиток, Китай.

The article outlines the main approaches to the organization of education of gifted children in China. It is established that the strategies and content of education of gifted children in Ukraine and China have both similarities and specific features. An analysis of the state-regulated education system for gifted children in China is presented.

Key words: educational process, educational institutions, gifted children, development, China.

Освіті обдарованих дітей у Китаї надається дуже велике значення, а підвищення інтелектально-творчого потенціалу в цій країні виходить на перше місце як засіб досягнення економічного благополуччя та процвітання [1, с. 27-28].

Розвиток системи роботи з обдарованими дітьми у країні має тривалу історію, яка розпочалася з 1978 року у процесі модернізації економіки та освіти КНР. Нині освіта обдарованих дітей введена в ранг державної політики. Необхідно наголосити, що у Китаї склалася централізована державна система освіти 3 національними мандатами, навчальними планами та оцінками [3].

За основу роботи з обдарованими дітьми у Китаї взято визначення обдарованості та моделі, створені в Америці та Європі. Утім зазна- 
чимо, що використання закордонного досвіду не порушило культурної своєрідності цієї країни, а доповнило роботу з обдарованими дітьми раніше відсутніми механізмами та положеннями.

Основний відбір учнів відбувається на рівні середньої школи 3 серйозним конкурсом на основі тестів. Прийом на черговий рівень навчання (середня школа, старша школа чи університет) визначається виходячи $з$ екзаменаційних завдань. Частка учнів, які продовжують освіту в університетах, дуже незначна. Приблизно лише один відсоток китайських учнів досягають цього рівня освіти.

Щодо освіти в Китаї взагалі, то зазначимо, що основою «китайського дива» є великі успіхи цієї країни в галузі освіти. Китай сьогодні домігся загальної грамотності і створив ефективну систему освіти. Успіхи країни пов'язані з політикою освіти, тому нині більшість китайських дослідників виявляють інтерес до питань навчання обдарованих дітей [2].

Нині державна політика в галузі освіти обдарованих учнів у Китаї передбачає такі можливості для найбільш талановитих дітей: більш ранній вступ до школи або перехід через клас, спеціалізовані класи, спеціалізовані школи, спеціальна діяльність у класі та поза школою, а також спеціальні програми для вихідних днів та канікул. Дані форми навчання вважаються в Китаї найбільш ефективними, і діти, які навчалися за цими програмами, дають значно більшу віддачу, ніж їхні однолітки, які не отримали такої можливості. Основними завданнями, що стоять перед фахівцями освітньої галузі щодо обдарованих школярів у Китаї, є: створення спеціальних навчальних програм, що відповідають особливим потребам обдарованих учнів у здобутті знань та високому рівню їхнього інтелекту, організація спеціалізованих шкіл для обдарованих школярів, організація позакласної роботи з обдарованими дітьми, для більш раннього закінчення середньої школи та вступу до ЗВО [3].

Зазначимо, що обдаровані діти та молоді люди в Китаї, як правило, користуються різними пільгами у навчальному процесі - до їхніх послуг державні стипендії, субсидії підприємств, організацій тощо. Водночас все більшого поширення набувають приватні (недержавні) університети. У Китаї створено ієрархічну систему спеціалізованих шкіл: у всіх містах та провінціях виділяється кілька найкращих шкіл, серед них найкраща називається «супершколою». Такі школи отриму- 
ють державну підтримку, i, головне - право конкурсного відбору. Прикладом такої школи є Shanghai High school, заснована 1865 році. Це одна із найстаріших шкіл у Китаї.

Особливу роль, на нашу думку, у роботі з обдарованими дітьми у Китаї відіграє додаткова освіта. В кожній школі є гуртки, що дозволяють розвивати різні типи обдарованості. Китайська система освіти обдарованих дітей передбачає наявність великого різноманіття спеціальних та комплексних програм.

Особливий інтерес представляє модель освіти обдарованих учнів, розроблена та реалізована у Гонконгу [3]. Відповідно до цієї моделі метою освіти $є$ вивчення та розвиток потенціалу обдарованих учнів шляхом систематичного надання учням можливостей отримання освіти відповідного рівня шляхом гнучкого навчання у спеціально організованому освітньому середовищі. Відповідно до цієї мети в основі описуваної моделі закладено принципи: розвиток різних видів інтелекту є прямою і головною метою якісної освіти і має бути місією всіх шкіл, особливі потреби обдарованих учнів повинні бути задоволені в їхній власній школі, ключовим моментом освіти обдарованих дітей має стати розвиток не тільки інтелекту, а й креативності та соціальних навичок, школи повинні послідовно надавати різноманітні види навчальних активностей на різних вікових щаблях, зокрема інтеграції різних внутрішньошкільних та позашкільних ресурсів.

Відповідно до описаних цілей, система освіти для обдарованих учнів у Китаї представляється шляхом включення основних елементів навчання обдарованих учнів (розвиток когнітивних навичок, креативності, особистісної та соціальної компетентності) до програм, орієнтованих на всіх учнів. Диференціація викладання шляхом визначення групи учнів відповідно до їхніх потреб шляхом поглиблення та розширення навчальної програми всіх навчальних дисциплін у звичайних класах.

Аналіз досвіду роботи з обдарованими дітьми показує, що сьогодні виявлення обдарованих учнів, створення умов для прояву їх унікального потенціалу стає одним з основних напрямів, як української системи освіти, так і китайської, при цьому система ідентифікації обдарованих дітей в Україні та в Китаї має подібності та відмінності.

Отже, порівняльний аналіз досвіду роботи з обдарованими учнями в Україні та Китаї дозволив встановити, що у країнах робота з обдаро- 
ваними дітьми введено до рангу державної політики. У Китаї існує централізована система роботи з обдарованими дітьми, що регулюється державою. Це стосується як країни загалом, так і їі регіонів.

Стратегії та зміст навчання обдарованих дітей в Україні та Китаї мають як подібність, і специфічні особливості. Якщо в Україні освіту обдарованих дітей спрямовано, переважно на когнітивну сферу, то в Китаї - $з$ опорою на національні традиції розвивається як когнітивна сфера, і особистісна сфера, включаючи духовність.

\section{Список використаних джерел:}

1. Коваленко О. А., Жерновникова О. А. Виховання інтелектуальної еліти нації: зарубіжний та вітчизняний досвід. Рідна школа. 2021. Вип. 3. C. 25-29.

2. Yankovych O. I. Suzuki Method in the training prospective specialists in preschool education. Journal of Education, Health and Sport. 2020; 10(12):162167. URL:https://apcz.umk.pl/czasopisma/index.php/JEHS/article/view/ JEHS.2020.10.12.

3. 刘霞. 通过音乐教育 促进幼儿全面发展-访北京师范大学王懿颖副教授 [J]. 教育 导刊, 2002, (08):4-5. 